
JURNAL
Vol. 2 No. 1 Januari 2020 : 57-63
SABHANGA
e-journal.stikessatriabhakti.ac.id

\title{
HUBUNGAN DUKUNGAN KELUARGA DENGAN MEKANISME KOPING PADA PASIEN PASCASTROKE DI POLI SYARAF RUMAH SAKIT UMUM DAERAH NGANJUK
}

\author{
Ganda Ardiansyah ${ }^{1}$, Henny Purwandari ${ }^{1}$, Ririn Subandiyah Hariati ${ }^{2}$ \\ ${ }^{1}$ Dosen Program Studi Pendidikan Ners Stikes Satria Bhakti Nganjuk \\ ${ }^{2}$ Mahasiswa Program Studi Pendidikan Ners Stikes Satria Bhakti Nganjuk \\ Email : ririnsubandiyah@gmail.com
}

\begin{abstract}
Introduction:Stroke (circulatory disorders of the brain) is a neurological disease. Post-stroke patients with permanent disability due to residual symptoms experience stress levels that affect coping mechanisms. different levels of stress there is no support from the family. This study aims to determine the relationship of family support with coping mechanisms of post-stroke patients in the neurology of Nganjuk Hospital.Methods: Correlation research design with cross sectional approach was carried out on March 5-10 2018 population of 55 patients who met the inclusion criteria of 45 respondents with accidental sampling sampling technique. Independent variables of family support with questionnaire and dependent variable coping mechanism with questionnaire. Data were analyzed by statistical contingency coefficient test with $\alpha=0.05$.Result: The results of the study showed that out of 45 respondents, 24 respondents $(53.3 \%)$ had good family support, almost all of them were 39 respondents $(86.7 \%)$ had adaptive coping mechanisms. The results obtained $\rho$ value $=0.001 \leq \alpha=$ 0.05 , so $\mathrm{Ha}$ is accepted. This shows that there is a relationship between family support and coping mechanisms in patients after stroke at the Nervous Hospital of Nganjuk Hospital.Conclusions: Family support is proven to be a factor that enhances coping mechanisms. The family must be more effective in carrying out its role in supporting the treatment of sick family members namely motivating, providing facilities and giving more attention to patients.
\end{abstract}

Keywords: Family support, coping mechanisms, post-stroke patient 


\section{PENDAHULUAN}

Stroke atau gangguan peredaran darah otak (GPDO) merupakan penyakit neurologis yang sering dijumpai dan ditangani secara cepat dan tepat (Muttaqin , 2012). Pasien penderita pascastroke, khususnya yang mengalami cacat permanen sebagai akibat gejala sisa akan mengalami tingkat stress yang berbeda. Diantara penyebab perbedaan tingkat stress adalah ada tidaknya dukungan dari pihak keluarga, bagaimana mereka tidak hanya menerima keadaannya, tetapi juga membantu memenuhi kebutuhannya (Agustini, 2010). Hal ini membuat seseorang menjadi termotivasi untuk melakukan sesuatu demi mengurangi stress. Hal-hal yang dilakukan tersebut merupakan bagian dari koping. Hasil pengamatan dan wawancara yang dilakukan peneliti pada tanggal 20 Oktober 2017 dengan 4 pasien pascastroke di poli saraf RSUD Nganjuk didapatkan 2 pasien diantar oleh keluarga dan 2 pasien datang berobat sendiri. Dua pasien yang diantar keluarganya menunggu antrian dengan berkomunikasi bersama keluarga yang mengantar dan pasien yang lainnya sedangkan 2 pasien yang datang berobat sendiri tidak berkomunikasi dengan pasien lainnya dan beberapa kali datang ke ruang pemeriksaan untuk meminta segera didahulukan pemeriksaannya.
Stroke merupakan penyebab kematian ketiga di dunia setelah penyakit jantung koroner dan kanker baik di negara maju maupun negara berkembang. Satu dari 10 kematian disebabkan oleh stroke (Ennen, 2004; Marsh\&Keyrouz， 2010; American Heart Association, 2014; Stroke forum, 2015). Secara global, 15 juta orang terserang stroke setiap tahunnya, satu pertiga meninggal dan sisanya mengalami kecacatan permanen (Stroke forum, 2015). Stroke merupakan penyebab utama kecacatan yang dapat dicegah (American Heart Association, 2014). Prevalensi stroke di Indonesia berdasarkan diagnosis tenaga kesehatan sebesar 7 per mil dan yang terdiagnosis tenaga kesehatan atau gejala sebesar 12,1 per mil. Prevalensi Stroke berdasarkan diagnosis nakes tertinggi di Sulawesi Utara (10,8\%), diikuti DI Yogyakarta (10,3\%), Bangka Belitung dan DKI Jakarta masing-masing 9,7 per mil. Prevalensi Stroke berdasarkan diagnosis nakes jawa timur menduduki peringkat ke 4 (Riskesdas, 2013). Berdasarkan hasil diagnosis dari Dinas Kesehatan Kabupaten Nganjuk didapatkan prevalensi penderita stroke tahun 2017 bulan januari sampai September sebesar 7,24\% pasien stroke. Jumlah pasien pascastroke di poli saraf RSUD Nganjuk pada bulan oktober 2017 adalah 918 tiap bulan. 
Serangan stroke dapat menyebabkan berbagai macam gangguan, baik dari ketidakmampuan untuk dapat sembuh total, ringan sampai berat bahkan dapat mengakibatkan meninggal. Salah satu yang paling sering adalah rusaknya pusat gerakan otot-otot di otak, sehingga berbagai otot menjadi lemah atau tidak mampu bergerak (Hadi, 2004). Ketua umum Yayasan Stroke Indonesia, Sudomo berpendapat bahwa Insan Pascastroke (IPS) biasanya akan merasa rendah diri dan emosinya tidak terkontrol dan selalu ingin diperhatikan sehingga menimbulkan harga diri rendah pada seseorang dengan pasca stroke (Yastroki, 2012). Pada situasi yang berbahaya dan mengancam, koping yang berhasil akan mengurangi atau menghilangkan sumber masalah dan penyembuhan akan terjadi, akibat yang ditimbulkan bila koping pasien desruktif yaitu proses penyembuhan pasien akan terhambat karena tidak ada niat atau semangat di hati pasien untuk sembuh. Jika masalah koping pasien tersebut dibiarkan maka dapat berdampak pada penurunan harga diri pasien (HDR), stress, depresi, dan frustasi.

Dibutuhkan suatu usaha untuk bisa mengatasi stres ataupun masalah-masalah yang sedang dihadapi, usaha yang dilakukan dikenal dengan istilah coping (Sundberg; Winebarger; Taplin, 2011).
Dukungan keluarga yang diberikan memudahkan subjek dalam memunculkan mekanisme koping. Peran perawat dimulai dari tahap akut hingga tahap rehabilitasi, serta pencegahan terjadinya komplikasi pada pasien stroke (National Institute of Neurogical Disorder and Stroke, 2008). Peran perawat pada tahap pasca rehabilitasi bukan hanya dalam hal pencegahan komplikasi dan mengurangi factor resiko terjadinya stroke berulang, tetapi juga mengidentifikasi kebutuhan akan perencanaan pulang yang sesuai dengan kebutuhan pasien, dan memberikan informasi yang dibutuhkan, serta mendorong keluarga untuk lebih efektif dalam memberikan motivasi dan dukungan pada keluarga yang sakit. Hasil penelitian Hasan dan Rufaidah (2013) menunjukan semakin tinggi dukungan yang bersumber dari keluarga yang diperoleh penderita akan semakin baik pula mekanisme koping yang dimunculkan oleh penderita stroke. Berdasarkan fenomena dan hasil studi pendahuluan tersebut, peneliti tertarik mengambil judul tentang hubungan dukungan keluarga dengan mekanisme koping pasien pascastroke di poli syaraf RSUD Nganjuk.

\section{METODE PENELITIAN}

Penelitian ini menggunakan desain penelitian Korelasi, dengan pendekatan cross sectional. Dalam penelitian ini 
variabel independen adalah dukungan keluarga dan variabel dependen adalah mekanisme koping. Pengumpulan data untuk variabel independen menggunakan Kuesioner Dukungan Keluarga. Indikator Dukungan Keluarga yaitu Baik jika prosentase skor $=76 \%-100 \%$,Cukup jika prosentase $56 \%-75 \%$, dan Kurang jika prosentase skor $\leq 55 \%$.Dan variabel dependenmenggunakan Kuesioner Mekanisme Koping. Indikator Mekanisme koping yaitu Adaptif jika prosentase skor $\geq$ $76 \%$ dan Maladaptif jika prosentase skor $<$ $76 \%$.

Penelitian dilaksanakan tanggal 510 maret 2018 di Poli Syaraf Rumah Sakit Umum Daerah Nganjuk. Populasi dalam penelitian ini adalah 221 pasien pascastroke yang berobat ke Poli Syaraf RSUD Nganjuk sesuai dengan kriteria inklusi, yaitu Pasien pascastroke dengan serangan stroke pertama, pasien pascastroke yang tinggal bersama keluarganya, pasien pascastroke yang bersedia dijadikan responde, dan pasien pascastroke yang mampu berkomunikasi dengan baik.Sampel diambil dengan teknik Accidental Sampling dan diperoleh sebanyak 45 responden. Data yang telah dikategorikan kemudian dianalisa dengan uji koefisien kontingensi dengan $\alpha=0,05$.

\section{HASIL PENELITIAN}
Tabel 1
Tabulasi
Silang
Dukungan
Keluarga Dengan Mekanisme
Koping Pada Pasien Pascastroke Di
Poli Syaraf RSUD Nganjuk
Tanggal 5-10 Maret 2018.

\begin{tabular}{|c|c|c|c|c|c|c|}
\hline Dukungan & \multicolumn{3}{|c|}{ Mekanisme Koping } & \multicolumn{2}{c|}{ Jumlah } \\
\hline Keluarga & Adaptif & \multicolumn{2}{|c|}{ Maladaptif } & \multicolumn{1}{c|}{} \\
\hline & F & $\%$ & $f$ & $\%$ & $\Sigma$ & $\%$ \\
\hline Baik & 22 & 48,9 & 2 & $4,40 \%$ & 24 & 53,3 \\
\hline Cukup & 16 & 35,6 & 1 & $2,20 \%$ & 17 & 37,8 \\
\hline Kurang & 1 & 2,2 & 3 & $6,70 \%$ & 4 & 8,9 \\
\hline Jumlah & 38 & 86,7 & 6 & $13,30 \%$ & 45 & 100 \\
\hline$\rho$ & \multicolumn{8}{|c|}{ value $=0,001 \leq \alpha=0,05$} \\
\hline
\end{tabular}

Hasil tabulasi silang menunjukkan bahwa dari 45 responden, hampir setengahnya yaitu 22 responden $(48,9 \%)$ memiliki dukungan keluarga baik dan hampir seluruhnya yaitu 39 responden (86,7\%) mempunyai mekanisme koping adaptif.

Hasil uji koefisien kontingensi didapatkan $\rho$ value $=0,001 \leq \alpha=0,05$. Ha diterima sehingga ada hubungan dukungan keluarga dengan mekanisme koping pada pasien pascastroke di Poli Syaraf RSUD Nganjuk.

\section{PEMBAHASAN}

Dari hasil penelitian ini menunjukkandari 45 responden sebagian besar yaitu 24 responden (53,3\%) mempunyai dukungan keluarga yang baik. Dari 24 responden 12 responden (50\%) memiliki usia 45-54 tahun dengan nilai $\rho$ value usia $=0,03$ dan 23 responden 
$(95,8 \%)$ memiliki status pernikahan menikah. Dari data tersebut dapat disimpulkan bahwa usia dan status pernikahan mempengaruhi dukungan keluarga.

Pada tahap perkembangan artinya dukungan dapat ditentukan oleh factor usia dalam hal ini adalah pertumbuhan dan perkembangan, dengan demikian setiap rentang usia (bayi-lansia) memiliki pemahaman dan respon terhadap perubahan kesehatan yang berbeda-beda (Purnawan, 2008). Usia berkaitan dengan peran keluarga adanya perubahan sosial dan menyertai dalam proses penuaan. Sebab pada saat itu terjadi penurunan kontak sosial dan kesempatan untuk bertemu dengan orang banyak serta di dukung dengan keterbatasan fisik oleh karena proses penuaan itu sendiri sehingga berpengaruh pada intensitas kontak social (Gunarsa, 2004).

Peneliti beropini bahwa dukungan keluarga dipengaruhi oleh usia dan status perkawinan. Hampir setengah responden berusia 55-64 tahun, dimana seseorang tersebut lebih banyak membutuhkan perhatian dan dukungan dari lingkungan sekitar terutama keluarganya. Dukungan keluarga yang diberikan pada pasien pascastroke usia muda dengan lanjut usia sudah berbeda, karena prognosis pasien pascastroke usia muda dengan lanjut usia pun juga berbeda. Sebagian besar responden berstatus menikah, dukungan keluarga terutama pasangan sangat berpengaruh bagi pasien pascastroke untuk meningkatkan semangat pasien dalam menjalani pengobatan dan terapi yang harus dijalani.

Dari hasil penelitian ini menunjukkan dari 45 responden hampir seluruhnya yaitu 39 responden $(86,7 \%)$ mempunyai mekanisme koping adaptif. Dari 39 responden hampir seluruhnya yaitu 34 responden $(87,2 \%)$ memiliki status perkawinan menikah. Dari data tersebut dapat disimpulkan bahwa status perkawinan mempengaruhi mekanisme koping.

Faktor dukungan pasangan menjadi faktor penting yang turut memberikan kontribusi bagi respon emosi dan mekanisme koping subjek ketika sakit. Dukungan pasangan dipercaya dapat membantu para penderita untuk menghadapi penyakit yang dideritanya, dalam hal ini penyakit stroke (Smet, 1994 dalam Pratita Nurnina, 2012).

Peneliti beropini bahwa mekanisme koping dipengaruhi oleh status perkawinan. Sebagian besar responden berstatus menikah, dukungan social atau keluarga terutama pasangan sangat berpengaruh bagi pasien pascastroke untuk meningkatkan semangat dan memunculkan mekanisme koping yang adaptif pada pasien pascastroke. 
Dari penelitian ini didapatkan hasil uji koefisien kontingensi didapatkan $\rho$ value $=0,001$ pada $\alpha=0,05$ karena $\rho$ value $\leq \alpha(\alpha=0,05)$ makan Ha diterima dan Ho ditolak, sehingga ada hubungan antara dukungan keluarga dan mekanisme koping pada pasien pascastroke di Poli Syaraf RSUD Nganjuk dengan tingkat kekuatan lemah.

Dukungan keluarga dibutuhkan sebagai bantuan pada situasi stres maka akan mendapatkan kenyamanan fisik dan psikologis (Yusra, 2010). Pasien pascastroke membutuhkan dukungan keluarga yang baik untuk menghadapi stressor fisik dan psikologis akibat penyakit stroke. Dukungan sosial akan mengurangi ketegangan psikologis dan menstabilkan kembali emosi para penderita pasca stroke. Berdasarkan hasil penelitian dari Andarika (2004) mengungkapkan bahwa dukungan sosial yang diperoleh seseorang, maka semakin rendah ketegangan psikologis pada orang tersebut, sehingga dapat menciptakan penyesuaian diri yang positif kedalam masyarakat (Sarafino, 1998).Dukungan keluarga yang diberikan memudahkan subjek dalam memunculkan mekanisme koping. Hasil penelitian Hasan dan Rufaidah (2013) menunjukan semakin tinggi dukungan yang bersumber dari keluarga,diperoleh penderita akan semakin baik pula mekanisme koping yang dimunculkan oleh penderita stroke. Hal ini menunjukkan bahwa dukungan keluarga dengan aspek-aspek yang ada didalamnya dapat dijadikan sebagai prediktor untuk memprediksi mekanisme koping pada penderita stroke. Secara psikologis, apabila dukungan dari lingkungan sosial penderita stroke mampu mengoptimalkan aspek emosional, penghargaan, informasi, dan instrumental berupa perhatian, nasehat, saran, pemberian pekerjaan, dan sebagainya, maka dukungan sosial tersebut akan mampu meningkatkan mekanisme koping pada penderita stroke sehingga penderita merasa bahwa dirinya masih dibutuhkan, diperhatikan, dan merasa bahwa dirinya tidak berbeda dengan manusia yang lain. Dukungan sosial akan sangat diperlukan oleh penderita pasca stroke.

Opini peneliti berdasarkan teori dan fakta diatas adalah dukungan keluarga seperti mendampingi saat pengobatan, memberikan pujian, meluangkan waktu dan selalu memberi support, memberi informasi tentang pengobatan \& diet merupakan suatu tindakan yang mampu meningkatkan rasa percaya diri dan semangat pada pasien pascastroke. Dalam penelitian ini dukungan keluarga yang diberikan kepada responden sudah sesuai dengan teori. Peran perawat pada masalah ini yaitu mengidentifikasi kebutuhan akan 
perencanaan pulang yang sesuai dengan kebutuhan pasien, dan memberikan informasi yang dibutuhkan, serta memotivasi pasienuntuk tetap semangat dalam menjalani pengobatan dan memberi penyuluhan pada keluarga pasien untuk lebih efektif dalam melaksanakan perannya memberi perhatian yang lebih dan mendukung pengobatan anggota keluarga yang sakit.

\section{KESIMPULAN}

Kesimpulan dari penelitian ini adalah sebagian besarmempunyai dukungan keluarga baik pada pasien pascastroke di poli syaraf RSUD Nganjuk adalah 24 responden (53,3\%).Hampir seluruhnya pasien pascastroke di poli syaraf RSUD Nganjuk memiliki mekanisme koping adaptif sebanyak 39 responden (86,7\%).Ada hubungan dukungan keluarga dengan mekanisme koping pada pasien pascastroke di Poli Syaraf RSUD Nganjuk dari penghitungan SPSS didapatkan nilai signifikan $p$ value $=0,001 \leq \alpha=0,05$ maka $\mathrm{Ha}$ diterima.Untuk peneliti selanjutnya diharapkan dapat menambah variabel baru dalam melakukan penelitian dan penelitian ini bisa dijadikan sebagai referensi.

\section{DAFTAR PUSTAKA}

Muttaqin, A. (2012). Asuhan Keperawatan Dengan Gangguan Sistem
Persyarafan. Jakarta: Salemba Medika.

National Institute of Neurological Disorders and Stroke. (2008). Retrieved from Post-stroke Rehabilitation Fact Sheet: http://www.ninds.nih.gov/disorders /stroke/poststrokerehab/.htm (diakses pada tanggal 25 september 2017. Jam 14.30)

Yastroki. (20012). Stroke Penyebab Kematian Urutan Pertama di Rumah Sakit Indonesia. Retrieved from http://www.yastroki.or.id (diakses pada tanggal 16 oktober 2017. Jam 15.30)

Hasan, N., \& Rufaidah, E. R. (2013). Hubungan antara Dukungan Sosial dengan Strategi Koping pada Penderita Stroke RSUD Dr. Moewardi Surakarta. Talenta Psikologi. 